\title{
COMPETITION IN INDIAN SKY, FLY HIGH OR NOSE DIVE...
}

Shyju PJ*

\section{Introduction}

Indian aviation is experiencing a tremendous change in the recent years. Opening of Indian sky for private players made a paradigm shift in domestic air travel. After 1992 the role of Indian Airlines, the leading domestic carrier, has been showing a downward trend in market share and profitability. With the take off of Air Deccan, the first no fringe airline in India, made a sea change in the aviation sector by simplifying the procedures and offering lowest fares, which allowed the middle class to venture air travel. Merging of Air Sahara and Jet Airways indicates changes in the domestic aviation. As the Indian economy showing an upward trend, many industrialists looking opportunities in investing travel business. From the initial hick ups, domestic airline industry moves to an era of consolidation of travel business and co-operation in the market than competing each other to occupy a safer position in the market.

\section{Price War - A World View}

It can be seen that elsewhere in the world, low-cost airlines have garnered a big share of traffic by connecting profitable short-haul routes. The beginning of

* Lecturer, Dept. of History of Arts and Tourism, Banaras Hindu University, Varanasy, India, Email:pjshyju@rediffmail.com 
cheap air travel was with Freddie Laker,' who built an airline empire on low cost international travel. In the 1970s Laker Airways low fare sky train service from Britain to US opened new vistas for millions of tourists who has previously regarded air travel as a preserve of rich. In 1977, offering one way fare of $\$ 100$ between London - New York sparked a price war and major airlines rushed to follow its lead, many of them going to be red as a result.

Low-cost airlines have stormed the bastions in the US and Europe by Easy Jet, (UK), Ryan Air, (Ireland) which offers lower fares ${ }^{2}$. To entrepreneurs who have seen their success, a country of a billion price-conscious consumers probably seems ripe for the picking. In United States Air Tran (formerly the much derided Value Jet) and Jet Blue are leading the low cost aviation sector.

Two years ago, a discount carrier, Air Asia, was launched in Malaysia while Indonesia already has two fledging Low Cost Carriers(LCCs) - Lion Air and Air Paradise. Thai Airways has also set up its own low-cost airline, Nok Air that will run a series of flights on domestic routes to Chiang Mai, Hat Yai in the south and Udon Thani in the northeast. Budget airlines, it is estimated, will capture at least 25 per cent of Asia's air travel market within next 10 years and a lot of that will be new, not diverted, traffic. ${ }^{3}$ Singapore Airlines is the latest big player with its Tiger Ainways. Australia's national carrier Qantas will also be launching a lowcost subsidiary from Singapore. In July 2004, Singapore's first budget airline, Value air also started its operations between Singapore and Hong Kong. According to one estimate, at least a dozen LCCs will take to the skies to exploit the potentials of affordable air travel by Asia's growing middle-class

\section{The Indian Scenario}

The competition in Indian skies actually started in 1990s. East West Airlines, Modiluft, Damania Air were the leading private players offering services to metro cities and major competent to Indian Airlines. After few years of operations, huge loses forced these companies to wind up operations. Government support and monopoly of Indian Airlines continued till 1993 when Jet Airways started its operations with two Boeing Aircrafts. Air Sahara also entered in Indian aviation in 1993. In a short period of time both airlines could establish their foot in the market by offering flights in a regular and customer friendly way. Over a period of 50 years of the establishment of Indian Airlines, tough competition in the air travel market loosened sand from its feet. Its market share is reduced to 31 per cent in 2005 from 39.8 percent of 2003. ${ }^{4}$ Allians Air a subsidiary of Indian Airlines is incurring heavy losses and surviving with the Government support only. 
Acquisition of Air Sahara by Jet Airways further troubles the conditions of Indian Airlines. The old fleet of 70 aircrafts, surplus staff, higher operating expenditure and strikes by pilots and delays in schedules worsened the conditions. The changing of its brand name to Indian and purchase of 43 new aircrafts- Airbus A 320 , which will be delivered by 2010 , hope to give a new look to Indian.

\section{No Fringe Carriers to All Fringe Carriers}

As a no fringe airline Air Deccan was introduced in India in 2003, it violated all concepts of air travel in India. Flight ticket charges came down as low as Rs 500/- and untouched cities were also connected with the new airline. This was made possible by following actions from the side of air line. ${ }^{5}$

- Paid in-flight services - even a bottle of water costs.

- Lean staff pattern- the number of cabin crews were reduced from eight to four.

- Online booking and e ticketing - A piece of printed paper replaced the air ticket format itself.

- Less time in ground Aircrafts are in the sky for 14 hours comparing to 10 11 hours of Indian Airlines or Jet Airways.

- Single class travel - total number of seats were increased up to 180 in $\mathrm{A}$ 320 aircrafts which increased the seat capacity.

- Unexplored destinations- New destinations, which have connectivity only by train or bus given an opening.

- Targeting Middle class- the positioning of Air Deccan was to target the middle class who are traveling in AC First Class in railways. the reduced fare and traveling time attracted lot of people to the new airline.

- No frequent flyer programme - No promotional packages like points in Frequent Flyer programme

- Having a quick 20-minute turnaround for every flight - This permits the airline in the air than in the ground.

- No cargo - this reduces the turnaround time. 
- Point to Point Flights. At present the airline is not having any contract with international carriers to share passengers. Usually flights get delayed due to any delay connecting flight.

- Savings from using the computer reservation package developed in the home country.

- Reducing the middle men, such as travel agents and transferring the full travel fare directly in to the airline account.

Kingfisher Airlines of the UB Group Chairman Vijay Mallya, and Paramount Airlines based its operations in Tamil Nadu are all fringe airlines. The main purpose is to connect various cities in South India to the Metroes initially. The business philosophy of these airlines are to offer quality and value services to the customers who prefer air travel. The single class seating configuration in Kingfisher airlines, which is known as Kingfisher Class offers inflight services, entertainments and modern facilities are available at the same price which is charging by other all fringe airlines.

Paramount Airlines is offering business class facilities at a lower fare. The concept of carry as many as passengers as possible is not the business strategy. Instead to meet the expectation level of customers or provide more than they expect in terms of quality and value.

Modiluft Airlines, which relaunched its services in the brand name of Spice Jet is another low cost carrier. Spice Jet also focuses to market its reliability and punctuality factors which distinguish it from others. ${ }^{6}$

IndiGo (Inter Globe Aviation) another low cost carrier planning to start its operations in July-August 2006. It promises lower fares, but hot foods will not be served in the cabin. There will not be any inflight entertainment or meal service apart from beverages. The airline has ordered 100 aircrafts and by 2007 it hopes to increase its fleet by 15. Indigo also aims to connect the two tier cities mainly business cities to Metroes. ${ }^{7}$ Go Air offering services to 11 cities with its fleet of 3 Airbus A 320s with 24 flights It started operations in November last year. The following list indicates the purchase deals of various airlines for coming years. 
Aircraft purchase deals by various Carriers

\begin{tabular}{|c|c|c|}
\hline Airline & No. of Aircrafts & Details \\
\hline Go $a r^{8}$ & 20 & $\begin{array}{l}\text { Airbus A } 320 \text { Aircraft, valued at } \$ 1.2 \\
\text { billion }\end{array}$ \\
\hline Spice Jet ${ }^{9}$ & 10 & $\begin{array}{l}5 \text { Boeing } 737-900 \text { Extended range } \\
5 \text { Boeing } 737-800 \text { Extended range } \\
\text { Total } 20 \text { in order }\end{array}$ \\
\hline IndiGo ${ }^{10}$ & 100 & $\begin{array}{l}\text { A } 320 \text { Family. include A319 and A321 } \\
\text { aircrafts }\end{array}$ \\
\hline King Fisher ${ }^{11}$ & 15 & ATR-72-50030 new aircrafts by 2008 \\
\hline Jet Airways ${ }^{12}$ & 10 & Boeing 737 \\
\hline Indian ${ }^{13}$ & 43 & 20 Airbus A319, 19 A321, 4 A 320 \\
\hline Paramount & 05 & Embraer \\
\hline Air India ${ }^{14}$ & 35 & Boeing Aircrafts \\
\hline
\end{tabular}

Air India also joined the group of low cost carriers by introducing Air India Express, the budget airline to manage the rush to Gulf Nations. In order to modernise its facilities and give a new look it has ordered Boeing aircrafts which can also be useful for the longhaul trips to US and U.K. Jet Airways poses new threats to Air India in its routes like London and New York soon. The reputation of Jet Airways in India and the merging of Air Sahara will permit Jet Airways to get good traffic in these routes.

\section{Airline}

Air Sahara

Jet Airways

Air Deccan

Spice Jet*

Kingfisher Airlines*

Jagson Airlines*

\section{Details of Passengers Flown, Destinations served}

3.5 million passengers in 2005, 27 aircraft, 28 domestic destinations

6.9 million Passengers 2005, 43 Aircraft $^{15}$

3.3 million since inception i.e, 2003, 28 Aircraft, 211 daily flights, 51 airports

5 Aircraft, 11 destinations

70 Flights a day

9 Destinations

* Data of passengers flown not available 
The schedule mentions clearly that there is a good prospect for the new airliners if they can manage the growing demand successfully. The opening of skies to US has shown a positive indication to operate Indian carriers to US. As Air Sahara is cleared the legal formalities to operate its services and Jet Airways is also on its way there will be a challenging task ahead of these carriers. To attract more customers from India, to US and Europe, British Airways, Lufthansa and Alitalia have come up with special packages.

\section{Problems ahead}

There are certain questions to be answered when various Carriers offer attractive packages to passengers and a new airline coming up in every month. It is obvious that the Indian economy is booming. The business deals and imitation of the west in terms of low cost carriers is not advisable for India is concerned. The challenges ahead are faced by every airlines -

- Parking fee

- Aircraft leasing charges

- Other operational costs like salary of the staff etc.

- Force to fly in unprofitable routes-government regulations

- Increase in aviation fuel price-ATF

- Sales tax charging by state governments.

- Delays by Air Traffic Controls

- Shortage of engineers

- Hiring of foreign pilots

- Poor infrastructure in airports.

It is also important to look the airport infrastructure in India where, Airport Authority of India could not change with the modern requirements. Passengers handled by the Airports under Airport Authority of India are increased almost four times from 1980 to 2003. Delhi airport is already facing problem with insufficient infrastructure to meet the growing demand. Studies shown that the busy air traffic raises question about the safety aspects of the passengers. Unlike in Europe or US, India do not have secondary airport, which may reduce the traffic and costs too. When flying to metros, they avoid the congested airport hubs and 
operate out of smaller secondary airports. This brings in considerable cost savings. Unnecessary delays in policy issues like modernization of airports and capping of Foreign Direct Investment ratio is another reason which may threaten the airline industry. Since much of the financial assistance to these industrialists is from foreign countries, there is also problem of foreign exchange leakages.

\section{Need of Co-operation and Consolidation}

The economic boom and healthy competition in the aviation sector has brought a qualitative change in Indian aviation sector. Acquisition and merging of Air Sahara and Jet Airways and tough competition from low cost carriers raises lot of question on the sustainability of future of aviation sector in India. But at the same time net work business and cooperation in technical expertise will help carriers to reduce costs. The plans of IPOs by Air Deccan give a hint of expansion of business. The establishment of training centre and hangar, infrastructure in various airports will add more employment opportunities. But the question of debts and profitability in operations are still making doubts in the industry that how long these competition continue.

Co branding of credit cards, and offering various services of other companies, agreements between the international carriers to share passengers can reduce the costs which are the means to survive the challenging situations.

\section{References}

1. The Hindu, February 11, 2006.

2. www.blonnet.com, June 26, 2005.

3. www.blonnet.com, January 19, 2004.

4. Business Line, February 25, 2006.

5. Business Today, January 30,2005 .

6. 4Ps, Vol- 2, Issue 1, August 2005.

7. Business Line, February 09, 2006.

8. Business Line, February 27, 2006.

9. Business Line, February 17, 2006.

10. Business Line, February 27, 2006.

11. 4Ps, Volume 2, Issue 6, January 2006. 
12. 4Ps, Volume 2, Issue 6, January 2006.

13. 4Ps, Volume 2, Issue 6, January 2006.

14. 4Ps, Volume 2, Issue 6, January 2006.

15. India Today, February 6, 2006. 